\title{
Research on the Influence of Institutional Environment and Fintech to Urban Commercial Banking Performance
}

\author{
Yang $\operatorname{Sen}^{1} \mathrm{Gu} \mathrm{Jijian}^{2, *}$ \\ ${ }^{1}$ School of Economics, Hubei Business college, Wuhan, Hubei 430079, China \\ ${ }^{2}$ Chongqing Vocational College of Transportation, Jiangjin, Chongqing 402247, China \\ *Corresponding author. Email: 406697814@qq.com
}

\begin{abstract}
As the main body of the financial industry, the operation of commercial Banks is related to the lifeline of the national economy. The integration and development of traditional finance and fintech is the trend of China's current financial reform. As a new form of finance resulting from the integration of the Internet and finance, there is a close relationship between fintech and the operating performance of commercial banks. Institutional environment is an important influencing factor for the development of the financial industry. Compared with the four major state-owned banks, urban commercial banks in China have significant regional institutional environment differences. Based on the development level of fintech and the influence of institutional factors on the business performance of commercial Banks, this paper explores the influence path and mechanism of fintech on the business performance of China's urban commercial Banks.
\end{abstract}

Keywords: institutional environment, financial technology, city commercial banking performance

\section{INTRODUCTION}

This paper first sorts out the relevant theoretical basis of technology spillover and new institutional economics, and focuses on the influence mechanism of fintech on the operating performance of urban commercial Banks through technology spillover and intermediate business. Based on the practice of New Institutional Economics in China, this paper also analyzes the action mechanism of China's government on fintech in terms of property rights environment and contract environment. And this paper also studies the influence of financial technology on the operating performance of city commercial banks. Finally, it is concluded that under the favorable institutional environment, fintech has a positive effect on the operating performance level of urban commercial banks.

\section{Fintech And Commercial Bank Performance}

\subsection{Fintech Improves The Performance of Urban Commercial Banks Based on Technology Spillover}

Technology spillover theory points out that the involuntary and unconscious technology diffusion of technology leading enterprises (spillover subjects) will have a positive impact on the technological progress of other enterprises in the same industry (absorption subjects). According to the technology spillover theory, fintech can promote the operational performance of urban commercial Banks through the following three approaches: demonstration effect, competition effect and connection effect.

\subsubsection{Demonstration effect}

City commercial bank has learned the concept of fintech companies to introduce smart terminal services and provide customers with financial service scenarios. The stronger the commercial bank's ability to establish a scenario, the more capable its innovative financial products and services will penetrate the real economy. Finally, the combination of information and fintech can increase the capacity of information collection and commercial Banks, and improve the ability of commercial Banks to "acquire customers" and "retain customers". Fintech companies provide China's commercial Banks with massive customer traffic and online data on the country's largest commercial Banks. In the cooperation process, commercial Banks and fintech companies complement each other's business advantages and share customer resources by improving the performance of commercial banks.

\subsubsection{Competition effect}

Fintech promotes the productivity development of commercial Banks through the effect of competition, which means that the development of fintech helps to eliminate the monopoly of the banking industry and 
improve the productivity of commercial Banks. On the one hand, advanced technology has helped commercial Banks break the time and geographical limits of financial services. On the other hand, fintech has improved the commercial skills of urban commercial Banks. The deep application of technologies such as cloud computing, artificial intelligence and blockchain has led to major and even disruptive changes in the field of risk management in commercial Banks. For example, the application of artificial intelligence models such as neural networks, expert systems, vector support and hybrid intelligence can improve data processing speed, deepen data analysis depth, reduce labor costs and improve the effectiveness of financial risk control.

\subsubsection{Connection effect}

Fintech establishes cooperation with commercial banks through linkage effects. Fintech can further help commercial Banks solve the problem of information asymmetry. On the one hand, commercial Banks in China have the "natural advantages" of scale of assets, customer base and government support. In the early stage of fintech development, commercial Banks with relatively sound financial system and relatively prudent operation mode can provide financial distribution for fintech companies. On the other hand, fintech has further reduced the operating costs of commercial Banks. First, investing in Internet infrastructure is the most straightforward way to reduce transaction costs. Second, it can isolate and optimize all types of process resources to minimize operating costs. Strengthen customer business process management, improve management efficiency. Finally, commercial Banks reduce channel costs, through comprehensive analysis, use a variety of channels to scientifically and reasonably arrange customer service choices, and change the way of traditional transaction Banks mainly rely on physical stores, which greatly reduces distribution costs to a certain extent.

\subsection{Fintech Improves the Performance of China's Urban Commercial Banks Based on Intermediate Business}

\subsubsection{Credit business}

Fintech further optimized the "resource allocation" function of commercial banks. In the process of absorbing deposits and lending internally, commercial banks have potential credit risks, while in the process of external financing, there are certain risks of information asymmetry. The Internet funds obtained based on fintech can effectively avoid these two types of risks.

\subsubsection{Third party payment}

Fintech can further improve existing commercial bank payment systems. Compared with traditional city commercial banks, FinTech provides more affordable payment and clearing services, which makes it the most effective financial leasing function.

\section{FINTECH, INSTITUTIONAL ENVIRONMENT, AND COMMERCIAL BANKING PERFORMANCE}

Due to China's gradual strategy of "advancing reform first and then", there are significant differences between regional reform process and institutional environment. Because the information was incomplete, the reformers had to use some of the information to make a decision, start experimenting and then scale it up. Through reform and opening up, China has achieved 36 years of sustainable economic growth and has gradually transformed its planned economy into a socialist market economy. In the final analysis, the miracle of China's traditional financial development today is the gradual reform strategy under the leadership of the government. This strategy has the advantage of unprecedented reform, but because of the gradual reform has also caused the institutional environment differences between China's regions.

\subsection{Institutional Environment and Fintech Development}

\subsubsection{Government regulation provides public goods for the development of fintech}

In the era of big data, it is of great commercial value to extend cloud data classification, classification, and review. The Internet is further sensitive to identifying credit risks of major financial issues and further improving the ability to identify risks. Because the Internet can more effectively identify credit risk, it also addresses the issue of information asymmetry in economic activity. Building infrastructure is a major challenge in the practice of fintech In addition to the basic infrastructure, such as credit information, credit expansion, securitization and liquidity guarantees are also very important. The existing credit information system of the people's bank of China mainly serves traditional financial institutions such as Banks. Traditional credit information systems still cannot benefit from fintech. It should strongly integrate the existing credit information system into a fintech service. Therefore, China urgently needs to establish a sound credit system in the field of fintech, and the establishment of credit information system is the most important. The government's investment in fintech public goods is not only the supervision of fintech practitioners, but also the promotion of financial science and technology. [1] 


\subsubsection{The government's institutional arrangements provide a favorable property rights environment for fintech}

Government is a large-scale institutional arrangement for the supply of public goods, the elimination of externalities, the distribution and redistribution of property rights[2]. The role of government intervention in China's fintech is mainly reflected in three aspects: first, technological innovation in the process of fintech development. The systematic risk brought by technology will lead to a large amount of external negative expenditure. Secondly, as the main government data display and construction of infrastructure, alleviates the problem of information asymmetry in the financial market and improves the financial efficiency; Third, the complexity and importance of fintech products cannot by themselves address the main risks they create. The resulting market risks are managed by the government to promote the fair and healthy development of the financial market. Effective political systems and financial market systems are mutually reinforcing. They can support and cooperate with each other, and ultimately promote the development of the financial market and the sustainable growth of the market economy[3].

\subsubsection{Government regulation creates a good contractual environment for fintech}

The government provides a good legal and contractual environment for fintech. Although financial innovation promotes social development and progress, it brings new risks. Financial risk is the basic element of financial activities, with infectivity. Financial innovation increased the accumulation of risk. Therefore, the government's supervision of fintech should be macro-prudential supervision and bottom-up supervision. When financial innovation does not touch the red line, external forces should not be used to restrain innovation. From the perspective of the government, on the one hand, the government cannot intervene in the development of the financial market beyond the law, and the protection of investors in the financial market requires strong legal protection from the government; On the other hand, to create a proper and good competition. The order of competition requires government support. Only the government can break down the barriers of interest groups and promote the development of financial markets. At the level of regulatory system, the existing legal system of the government can be applied to various fintech activities; Secondly, the existing legal system should be continuously incorporated into the financial science and technology activities not covered, so as to improve the law enforcement system. In addition, practice has proved that the original legal system is not in line with the reality of financial development. If it continues to be implemented, it will curb the development of fintech and hinder the release of traditional financial vitality. Some laws and regulations should be revised or deleted. In recent years, the Chinese government has continuously improved the basic legal structure of fintech and gradually promoted the legalization of fintech.

\subsection{Institutional Environment and Operational Performance of Urban Commercial Banks}

\subsubsection{The effect mechanism of institutional environment on the operating performance of urban commercial Banks}

Under the background of the influence of fintech development on the operational performance of commercial Banks, the influence of institutional factors on the operational performance of China's urban commercial Banks is studied. In the existing research, the consideration of institutional environment is mainly carried out from the macro and micro levels. At the macro level, the institutional environment in the region where the enterprise is located is represented by the level of marketization[4]. System of China's economic transition period a new binary structure, namely the traditional plan system structure and market system structure in the same political system of the communist party of China, due to the differences of two system structure strength combination, make them on the macro symbiosis formed a new regional development difference, different degree, the existence of a lack of market rules, market information transmission mechanism is not perfect, inefficient intermediary market mechanism, government action is difficult to predict and bureaucratic system of "defect". In other words, the degree of institutional development presents regional characteristics, which are reflected in the regional degree of marketization. Therefore, the degree of marketization, as a unit of institutional background, can be used to measure the macro-institutional environment in the region where the enterprise is located. The system at the micro level is the internal governance mechanism that constrains enterprise operation -- corporate governance. A large number of studies have proved that good corporate governance is a necessary condition for sustainable business operation. This paper only examines the institutional factors at the macro level, and quantification can directly reflect the institutional environment of the enterprise.

\subsubsection{Property environment}

China's urban commercial Banks are the product of policy dominance. On the one hand, they enjoy the government's support in terms of policies and resources; on the other hand, they are confronted with the government's intervention, which indicates that the government's governance environment has a dual impact on the stateowned urban commercial Banks. In general, the market 
economy is not perfect, so you need to promote and market mechanisms complement system construction, improve the government's rational regulation of the economy and society and the intervention mechanism to complement the lack of market mechanism but inappropriate government intervention will hinder market regulation, so for a bank is not conducive to the allocation of credit funds, and bank credit funds as its capital profit, so the government intervention will affect the performance of the bank.

Local governments in order to corresponding economic and political goals, the need to control a certain amount of financial resources to promote the local infrastructure, due to the limited fiscal revenue, at the same time, state-owned Banks business contract, loan authority taking, weakening the control ability of local government, therefore, the local government holding the position of the depend on the city commercial Banks to serve the local economy. In addition, according to the above analysis, such interventional allocation of financial resources, on the one hand, will not benefit bank performance by putting funds into non-profit projects; on the other hand, it will also bring good projects to the bank and increase the bank's customer resources, which is conducive to performance. It should be pointed out that different urban commercial Banks have different levels of local economic development due to geographical conditions. Therefore, government intervention has different effects on the performance of urban commercial Banks.

\subsubsection{Contract environment}

Due to the protection of laws in areas with a good legal environment, the neglected behaviors such as maliciously defaulting on bank accounts, evading debts and defaulting are greatly reduced, so that Banks can correspondingly reduce non-performing loans, thus increasing capital recovery, making more cash flow, and issuing more loans to win a win-win situation with enterprises. On the other hand, when the rule of law is better, because the information is more transparent and the self-serving operation of state-owned major shareholders is limited, the governance of urban commercial Banks is relatively standardized, which can also reduce the risks brought by related loans, shady operations and rent-seeking. When poor legal environment and credit asset quality cannot be guaranteed, so as to make the non-performing loans is, cause high non-performing loans, cause the city commercial Banks can't get positive profits from lending, and the associated enterprises through correlation with bank shareholders obtain the city commercial bank loans, which damage the city commercial bank's performance.

\subsubsection{The institutional environment strengthens the positive effect of fintech on the operational performance of urban commercial Banks}

A favorable institutional environment should have a lasting impact on the development of fintech to improve the performance of commercial city Banks. Fintech technology spillovers largely depend on good absorptive systems to escort contract execution[5]. In the new era of continuous improvement and innovation of the institutional environment, compared with large commercial Banks, China's urban commercial Banks can grasp the institutional advantages more keenly, better play the positive guiding role of fintech on traditional business, and finally achieve the effect of improving business performance. Large commercial Banks are a monopoly for a long time, also maintained a leading level in the financial business level, that is because the large firms in our country has a unique "gene", unclear property rights of large commercial Banks in the study's capacity to absorb the financial technology, investigate its fundamental is dependent on the "genetic traits of large firms. As a result, when the emergence of fintech has had a competitive effect, the big firms have reflexively chosen to rely on government aid to stay in the game, rather than blaze new technological trails to revive it. Second, the size and complexity of large commercial Banks have slowed their response to fintech.

The relationship between the local government and the market in the operation of urban commercial Banks has been clarified after the property rights reform because of the "small boat easy to turn around". As potential beneficiaries of fintech technology, urban commercial Banks are better than large commercial Banks in terms of resource constraint, property rights structure and business model.

In areas with a strong contractual environment, good legal and judicial systems will allow borrowers to protect their rights, and city commercial Banks will reduce Banks' concerns about delay in the legal rights, thereby increasing borrowers' confidence in city commercial Banks for the next loan. Good institutional constraints also reduce the possibility of default lenders, effectively reduce the cost of credit activities, play a role, and lubricate the impact of fintech development on the performance of Banks in commercial cities.

To sum up, the development of fintech will improve the operational performance of urban commercial Banks. In a good institutional environment, urban commercial Banks can make use of the good social relations formed by the system to further enhance the impact of fintech development on the operational performance of urban commercial Banks. In a poor institutional environment, local Banks may be limited by the lack of a good institutional environment to ensure the existence of economic and financial risks are difficult to resolve, so as to reduce the impact of fintech development on the performance of urban commercial Banks. 


\section{CONCLUSION}

Firstly, Fintech provides a new mode of communication for commercial Banks through demonstration effect, and fintech effectively improves the performance level of China's urban commercial Banks through technology spillover effect.

Secondly, the development level of fintech significantly affects the operating performance of China's urban commercial Banks through credit services, third-party payment and other intermediary businesses.

Finally, this paper explores the effect mechanism of the macro institutional environment on the operating performance level of commercial Banks. The institutional environment has a positive effect on the improvement of operational performance of urban commercial Banks.

\section{REFERENCES}

[1] Cao Tong. The primary challenge of Internet finance is infrastructure construction [N]. 21st Century Business Herald, 2015-01-14 (016).

[2] Zhao jingyi. Analysis on the mechanism of regional government competition and financial market innovation $[\mathrm{J}]$. Journal of science and technology economics, 2016(19):195.

[3] Zhao jing. Analysis on the legal path of Internet financial regulation -- from the perspective of "government-market" relationship [J]. Mudanjiang university daily,2017,26(04):82-84.

[4] Fan gang, Wang xiaolu, Zhu hengpeng. China marketization index -- 2011 report on the relative process of marketization in different regions [M]. Beijing: Economic Science Press, 2011.

[5] Shen yue, Guo pin. Internet finance, technology spillover and total factor productivity of commercial Banks [J]. Finance research,2015(03):160-175. 